Sustinere

Journal of Environment and Sustainability

Volume 2 Issue 3 (2018) 156-167

Print ISSN: 2549-1245 Online ISSN: 2549-1253

Website: https://sustinerejes.comE-mail:sustinere.jes@iain-surakarta.ac.id

\title{
RESEARCH PAPER \\ Fast decomposition of food waste to produce mature and stable compost
}

\author{
Ika Bagus Priyambada*, Irawan Wisnu Wardana \\ Dept. of Environmental Engineering, Faculty of Engineering, Diponegoro University, Indonesia
}

Article history:

Received 11 November 2018 | Accepted 29 December 2018 | Available online 31 December 2018

\begin{abstract}
Food waste can be meat, fish, cooked food scraps, moldy bread, bone scraps, cakes, expired foods, dairy products, fruits and vegetables. Food waste which is put into the trash will decay and produce a foul odor which in turn will invite flies and cause potentially diseases. Most of the food waste that is processed using the composting process needs to spend a relatively long time, which is about 1-3 months or even 6-12 months. This study aims to accelerate composting time through the addition of additive microorganisms in various quantities. Four aerobic composter reactors were utilized in this study. Variations of additive microorganisms added to the research object were 0 in reactor (control), $8 \mathrm{~g}$ in B2 reactor, 16 $\mathrm{g}$ in B3 reactor, and $32 \mathrm{~g}$ in B4 reactor. All reactors were added with dolomite lime. During the composting process temperature, $\mathrm{pH}$, water content and macroelement were tested. The results showed that the mature and stable compost was reached on the seventh day and produced from B2 reactor. In That reactor treated food waste and additive microorganisms with a ratio of 7:3, and $1 \mathrm{~g}$ dolomite lime. The level of $\mathrm{C} / \mathrm{N}$ ratio produced from $\mathrm{B} 2$ reactor was 16.71. The value of $\mathrm{C} / \mathrm{N}$ ratio was better than $\mathrm{B} 3$ reactor which produced $\mathrm{C} / \mathrm{N}$ of 18.37 . The control reactor produced a $\mathrm{C} / \mathrm{N}$ ratio of 21.84 and mature and stable compost was reached on the 14th day. All in all, this study was regarded to be successful in accelerating the degradation of food waste into mature and stable compost in just seven days.
\end{abstract}

Keywords: fast biodegradation; food waste; decomposition; compost stability, compost maturity

\section{Introduction}

According to Law Number 18 of 2008, waste is the rest material used in human daily activities and/or natural processes that are in solid form. Food waste consists of leftovers from meat and vegetables originating from the process of making, storing, selling, preparing, cooking, and serving the food (Tchobanoglous \& Kreith, 2002). Waste is a source of a problem that has often been faced by both developed and developing countries and until now the strategy of handling is still being developed. Food waste can be in the form of meat, fish, cooked food scraps, moldy bread, bone scraps, cakes, expired food, milk products, fruit and vegetables. When the

*Corresponding author. E-mail: ikabaguspriyambada@gmail.com DOI 10.22515/sustinere.jes.v2i3.47 
food waste is put into the trash, it will decay and produce a foul odor which in turn will invite flies. The amount of food waste generated from household activities is relatively high which is more than $60 \%$ and the other is a recyclable waste, such as plastic, paper, glass, and metal. Food waste cannot be recycled or sorted because it contains very high water content up to $74.5 \%$. This waste has the potential to produce pollutants in the form of leachate, odor and air pollution (Zhang et al., 2008). The process of decaying food waste will produce a slurry which prevents air flow so that the waste quickly turns into anaerobic. The anaerobic process releases stabbing odors caused by $\mathrm{H}_{2} \mathrm{~S}$ gas, $\mathrm{NH}_{3}$ and other volatile compounds. In the decay process, the food waste structure/fiber is weakened and the water will be released into leachate (Zhang et al., 2008).

Most food waste is synthesized through a composting process. However, it will take a relatively long time, which is around 1-3 months or even 6-12 months. To maximize composting, it is necessary to ensure that the degradation process of organic matter takes place effectively and efficiently (Fan et al., 2017). Justice et al. (2010) states that fundamental knowledge of the composting process is very important to ensure the sustainability of composting. This requires setting clear parameters during composting such as ripening time, comparison of bulking agent and waste, aeration, the emergence of leachate, and strong odor. In addition, the development of microbes and the emergence of high temperatures can be act as an indicator of the composting process speed. Controlling the composting process parameters will leading it to be more efficient, produce low gas emissions, and produce quality compost (Barrena et al., 2014).

The process of decomposition of solid waste can be accelerated by regulating the particle size (Bernal et al., 2009). The distribution and size of particles of solid waste affect the growth area of decomposing microorganisms and maintain sufficient porosity for the aeration process. The large size of the particles of solid waste makes the microorganisms unable to reach the middle of solid waste which leads to the slow decomposition. Food waste needs to be enumerated first so that the particle size becomes smaller and homogeneous.

Composting can take place faster with the help of microorganisms. Microorganisms have an important role in the process of decomposition of food waste. Various types of microorganisms collectively decompose food waste. Microorganisms involved in composting will grow according to temperature, which signifies various steps in the decomposition process (Keener et al., 2000). The process of decomposition of food waste needs to get assistance from microorganisms outside the medium (additive microorganism). Some previous research shows that mature and stable compost can be used as a source of microorganisms to accelerate the decomposition process. The composition of raw materials is $40 \%$ manure and $60 \%$ leaf waste (Azizah et al., 2017).

Based on this background, a clearer understanding of the number of additive microorganisms that must be added is very important so that the compost maturation can run faster. This study analyzes the fast composting process (fast biodegradation) in detail. The hypothesis of this research is that the process of composting food waste can take place within a 1-2 week period. The indicators of compost quality include the level of stability, maturity, and speed of degradation of food waste. 


\section{Literature review}

\subsection{Food waste}

According to Tchobanoglous \& Kreith (2002), food waste consists of remaining food that is not eaten and waste when making food from households, commercial businesses (restaurants), institutions (schools, colleges and hospitals), and some industrial sources (lunch at the company). Food waste is the animal and vegetable waste resulted from making, storing, selling, preparing, cooking, and serving food. The density value for food waste is 1 pound $/ \mathrm{m}^{3}$ or 0.453 $\mathrm{kg} / \mathrm{m}^{3}$. The moisture content of food waste is $50-80 \%$.

\subsection{Composting}

Compost is the result of decomposition of organic matter through biological processes with the assistance of decomposers. The decomposition process can be aerobically or anaerobically (Tchobanoglous \& Kreith, 2002). The advantage of compost is that it has the complete macro and micronutrient content. Macronutrients contained in compost include $\mathrm{N}, \mathrm{P}, \mathrm{K}, \mathrm{Ca}, \mathrm{Mg}$, and S, while the micronutrients content include $\mathrm{Fe}, \mathrm{Mn}, \mathrm{Zn}, \mathrm{Cl}, \mathrm{Cu}, \mathrm{Mo}, \mathrm{Na}$ and $\mathrm{B}$ (Pereira et al., 2012). The aerobic composting process does not require too long duration and does not produce odor, because of the presence of aerobic bacteria. The microbiological decomposition process is characterized by the loss of mass and volume of organic material. The results of the aerobic composting process are dry ingredients with less than 50\% moisture, dark brown, and crumbs. Aerobic microbes take oxygen and water from the air. The food is obtained from organic materials which will be converted into metabolic products in the form of carbon dioxide $\left(\mathrm{CO}_{2}\right)$, water $\left(\mathrm{H}_{2} \mathrm{O}\right)$, humus, and energy. Some of the energy produced is used by microbes for growth and reproduction, and some will be released into the environment as heat. Simanungkalit et al. (2006) formulated the reaction of the aerobic composting process is as follows:

$$
\text { Organic material }+\mathrm{O}_{2} \stackrel{\text { Aerob Microbe }}{\mathrm{N}, \mathrm{P}, \mathrm{K}} \mathrm{H}_{2} \mathrm{O}+\mathrm{CO}_{2}+\text { Nutrient }+ \text { Humic }+ \text { Energy }
$$

Table 1 The comparison between aerobic and anaerobic composting

\begin{tabular}{|c|c|c|}
\hline Characteristics & Aerobic process & Anaerobic process \\
\hline $\begin{array}{l}\text { Formation } \\
\text { reaction }\end{array}$ & $\begin{array}{l}\text { Exothermic requires energy from the } \\
\text { outside, produced by heat }\end{array}$ & $\begin{array}{l}\text { Endodermis does not need energy from } \\
\text { outside, produced by bio-energy sources }\end{array}$ \\
\hline $\begin{array}{l}\text { The final } \\
\text { product }\end{array}$ & Humic, $\mathrm{CO}_{2}, \mathrm{H}_{2} \mathrm{O}$ & Mud, $\mathrm{CO}_{2}, \mathrm{H}_{2} \mathrm{O}$ \\
\hline $\begin{array}{l}\text { Volume } \\
\text { reduction }\end{array}$ & More than $50 \%$ & More than $50 \%$ \\
\hline Processing Time & (20-30) days & (20-40) days \\
\hline $\begin{array}{l}\text { The main } \\
\text { purpose }\end{array}$ & Volume reduction & Energy production \\
\hline Side goals & Compost production & Waste stabilization \\
\hline Aesthetics & Does not cause odor & Smelly \\
\hline
\end{tabular}




\subsection{Factors affecting the composting process}

Tchobanoglous and Kreith (2002) stated that in general, the factors that most influence the composting process are the characteristics of the composted material, the selected bio-activator, and the composting method. The factors that influence the composting process are presented in more detailed as follows.

\subsubsection{The ratio of $\mathrm{C} / \mathrm{N}$}

Charcoal or carbon (C) and nitrogen $(\mathrm{N})$ are found in all parts of organic waste. In the composting process, $\mathrm{C}$ is an energy source for microbes while $\mathrm{N}$ functions as a food and nutrition source for microbes. The $\mathrm{C} / \mathrm{N}$ ratio is determined based on the type of waste, but the most effective for the composting process ranges from 30:1 to 40:1. Microbes break down compound $\mathrm{C}$ as an energy source and use $\mathrm{N}$ for protein synthesis. At the $\mathrm{C} / \mathrm{N}$ ratio between 30 and 40, microbes get enough $\mathrm{C}$ for energy and $\mathrm{N}$ for protein synthesis. If the $\mathrm{C} / \mathrm{N}$ ratio is too high, microbes lack $\mathrm{N}$ for protein synthesis so that decomposition will require a longer duration.

\subsubsection{The size of the particles}

Particle size greatly determines the amount of space between materials (porosity). A sufficient pore will allow air and water to be spread more evenly in the stack. To increase the surface area, the particle size of the material should be reduced to be $2-10 \mathrm{~cm}$ for a better result. Large particles will inhibit aeration and microbial performance so that the ripening process will take longer. In addition, the increasing contact between microbes and materials can accelerate the decomposition process (Tchobanoglous \& Kreith, 2002).

\subsubsection{Aeration}

Fast composting can occur when there is sufficient oxygen. Aeration naturally occurs when there is an increase in the temperature which will cause the warm air to come out while cooler air to enter the compost pile. Aeration is determined by porosity, material particle size and material water content (humidity). If aeration is hampered, the comparison of carbon and nitrogen in various organic ingredients can result in an anaerobic process that will produce strong-smelling ammonia. Aeration can be increased by reversing or flowing air into the compost pile.

\subsubsection{Temperature}

Heat is generated from microbial activity. The higher the temperature is, the more oxygen consumption and the faster the decomposition process is. The high amount of oxygen consumed in the microbial metabolism will produce more $\mathrm{CO}_{2}$ so that organic matter decomposes faster. An increase in temperature can occur quickly in the compost pile. Temperatures ranging from $30^{\circ} \mathrm{C}-60^{\circ} \mathrm{C}$ show fast composting activities. While temperatures higher than $60^{\circ} \mathrm{C}$ will kill some microbes and only thermophilic microbes will survive. High temperatures will also kill plant pathogenic microbes and weed seeds. When the temperature reaches $60^{\circ} \mathrm{C}$, we should immediately do a pile reversal or air distribution to reduce the temperature, because the thermophilic microbes will be easily killed.

\subsection{5 pH Level}

The composting process can occur at a pH range of 5.5 - 9. The composting process will cause changes in organic matter and the $\mathrm{pH}$ of the material itself. For example, the process of temporary or local acid release will cause a decrease in $\mathrm{pH}$ (acidification), while the production of ammonia from nitrogen-containing compounds will increase $\mathrm{pH}$ in the initial phases of composting. Mature compost pH levels are usually close to neutral. The condition of compost contaminated with rainwater can also cause increase the $\mathrm{pH}$ level. 


\section{Methodology}

\subsection{Research instrument}

The main equipment of this experiment is four pieces of reactors. They are tubular reactors with a height of $30 \mathrm{~cm}$ and a diameter of $23 \mathrm{~cm}$. They are made of plastic with an additional blower on the right side which is connected to a 2.5 inch diameter pipe. While on the other side there is a small pipe where leachate will flow once it is formed. At the top of the reactor is a hollow hole for circulating the air inside the reactor. A blower is driven using DC electricity. It can be turned off and turned on. The reactor scheme is shown in Figure 1.

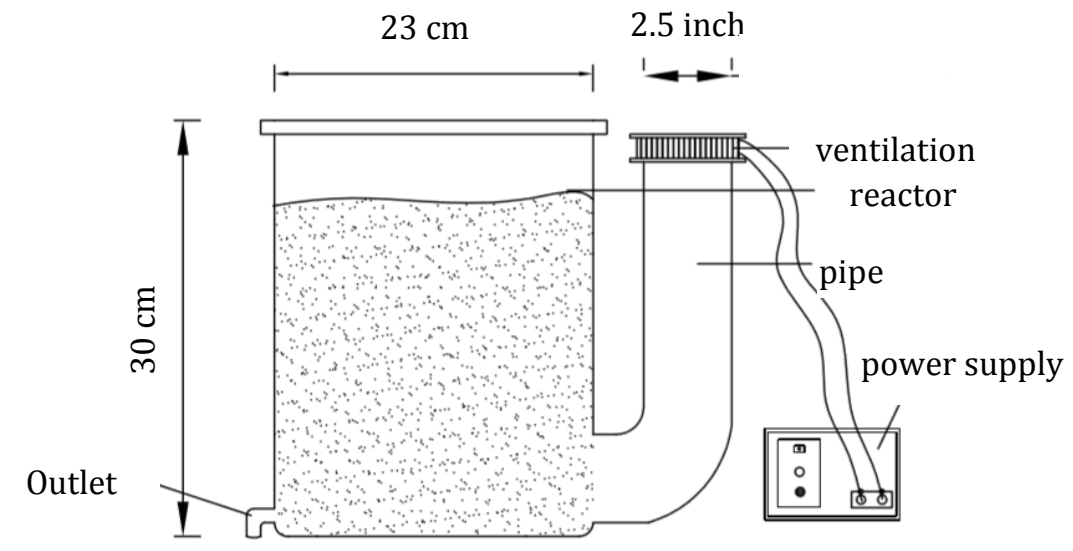

Figure 1. The reactor used in this study

\subsection{Food waste sources and research sites}

The research location is divided into two places. The first location is the site to get samples which is, in this case, the canteen of Electrical Engineering campus situated around $07^{\circ} 03^{\prime} 01.19^{\prime \prime} \mathrm{LS}$ and $110^{\circ} 26^{\prime} 23.01$ "BT. While the second location is where the test and sample analysis were conducted. It is located in the Environmental Engineering laboratory located around $07^{\circ} 03^{\prime} 01.93$ "LS and $110^{\circ} 26^{\prime} 25.09^{\prime \prime}$ BT.

\subsection{Research variables}

Three variables observed in this study included independent, dependent, and control variables. The independent variables in this study are the various amount of additive microorganism involved. While the dependent variable is the homogenous compost parameters including water content, temperature, and $\mathrm{C} / \mathrm{N}$ ratio

\subsection{Research steps}

Food waste is collected before it is put into the reactor with a mass of $4 \mathrm{~kg}$ in each. Four reactors and one grinding tool were applied in this study. Variations in the comparison of the amount of food waster and mature compost are presented in Table 1.

The initial characteristics of food waste used in the study were tested in the form of the $\mathrm{C} / \mathrm{N}$ ratio. Food waste is smoothed using a grinder. Food waste and additive microorganisms are put into the reactor and the blower is turned on for aeration. $\mathrm{pH}$ and temperature were checked out every day and the sample was tested on days 0,3 and 7 in the form of the $\mathrm{C} / \mathrm{N}$ ratio. The temperature was measured using the expansion method (mercury thermometer), $\mathrm{pH}$ measurement (SNI 06-6989.11-2004) and organic C using UV-Vis spectrophotometer (Genesys 
10s, Thermo Fisher Scientific). The wastewater content was measured by real-time using a water level measuring instrument series SM1701B and verified by the gravimetric method heated at $70^{\circ} \mathrm{C}$ for 48 hours.

Table 2. The composition and treatment of reactors

\begin{tabular}{|c|c|c|}
\hline Reactor & Composition & Treatment \\
\hline Control & $\begin{array}{l}\text { Food waste: mature compost 7:3 + 1gr } \\
\text { dolomite }\end{array}$ & Without environmental bio-activator \\
\hline B1 & $\begin{array}{l}\text { Food waste: mature compost 7:3 + } 1 \text { gr } \\
\text { dolomite }\end{array}$ & 8 gram of additive microorganism \\
\hline B2 & $\begin{array}{l}\text { Food waste: mature compost 7:3 + 1gr } \\
\text { dolomite }\end{array}$ & 16 gram of additive microorganism \\
\hline B3 & $\begin{array}{l}\text { Food waste: mature compost 7:3 + 1gr } \\
\text { dolomite }\end{array}$ & 32 gram of additive microorganism \\
\hline
\end{tabular}

\section{Results and discussions}

\subsection{The evaluation of the ratio between food waste and bioactivator}

According to Azizah et al. (2017), the composting process is influenced by the characteristics of composted materials, bioactivators, and composting methods used. The characteristics of composted materials are shown in Table 2.

Table 2. The characteristics of composted material

\begin{tabular}{lcc}
\hline \multicolumn{1}{c}{ Parameter } & Compost & Food waste \\
\hline C-Organic (\%) & 12.79 & 34.97 \\
N-Total (\%) & 1.17 & 2.41 \\
C/N Ratio & 10.9 & 14.52 \\
P-Total (\%) & 0.03 & 0.024 \\
K-Total (\%) & 0.78 & 2.109 \\
pH & 7.4 & 3.6 \\
Kadar Air (\%) & 17.42 & 78.94
\end{tabular}

Note: Compost was taken from Diponegoro University's Integrated Waste Management Site (Tempat Pembuangan Sampah Terintegrasi/TPST)

Compost quality indicators based on the $\mathrm{C} / \mathrm{N}$ parameter, approaching the $\mathrm{C} / \mathrm{N}$ ratio of land was 10-20. The results showed a ratio of 7:3 and the addition of 1 gram of dolomite lime resulted in a $\mathrm{C} / \mathrm{N}$ ratio of 11.22 on the 21 st day, while other ratios produced a greater $\mathrm{C} / \mathrm{N}$. The overall results of the $\mathrm{C} / \mathrm{N}$ values for various variations are shown in Table 3.

Table 3. Various scores of $\mathrm{C} / \mathrm{N}$

\begin{tabular}{lc}
\hline \multicolumn{1}{c}{ Treatment } & Ratio C/N \\
\hline Food waste: mature compost(10:0) & 29.14 \\
Food waste : mature compost (9:1) +1 gr dolomite & 26.62 \\
Food waste: mature compost (8:2) +1 gr dolomite & 15.76 \\
Food waste: mature compost (7:3) +1 gr dolomite & 11.22 \\
\hline
\end{tabular}


A study conducted by Ariyanti (2018) used 50 gram compost bio-activator in every $10 \mathrm{~kg}$ of leaf waste. The compost riped and became stable within 14 days. In this study the weight of the mixing material for each reactor was $5 \mathrm{~kg}$.

\subsection{The evaluation of composting time}

\subsubsection{Temperature}

The temperature became a parameter of exothermic reactions and important factors that influence the evaporation of water and the degradation of organic compounds (Zhang et al., 2008). The main control indicator on the activity of microorganisms during the process of degradation of organic matter is the temperature. If the optimum temperature of microorganisms is reached, the composting process will run optimally as well. According to Ayuningtyas (2009) the optimum temperature of the composting process ranges between 33-55 ${ }^{\circ} \mathrm{C}$.

Temperature is observed to see the difference of composting speed based on variations of additive microorganism in each reactor. The research temperature data is displayed in degrees Celsius. The temperature of compost is measured by inserting a thermometer into as half of the compost height. The temperature of the compost was observed for 14 days using 14 measurements.

Based on Figure 2, it can be seen that the temperature in all reactors containing additive microorganism ranged from $26^{\circ} \mathrm{C}-57^{\circ} \mathrm{C}$. On day 0 , the reactor added with additive microorganism reached a temperature of $33^{\circ} \mathrm{C}$ while the control reactor reached $32^{\circ} \mathrm{C}$. the temperature increased significantly from day one to day three and it peaked on day two in reactor $\mathrm{B} 1$ which was $57^{\circ} \mathrm{C}$. This showed that on days one and three the temperatures peaked and microorganisms that worked was thermophilic microorganism. Thermophilic microorganisms live at $45^{\circ} \mathrm{C}-60^{\circ} \mathrm{C}$ and are responsible for consuming carbohydrates and proteins so that the compost material can be degraded quickly. These microorganisms include Aspergillus niger and thermophilic fungi. Some Aspergillus niger are able to remodel cellulose and hemicellulose so that decomposition begins to slow down and the highest temperatures are reached (Bernal et al., 2009). Sufficient oxygen supply will increase the activity of microorganisms so that it can accelerate the degradation process (Ayuningtyas, 2009). The addition of a bio-activator will make the microorganisms inside the compost more active which can be shown by an increase in temperature.

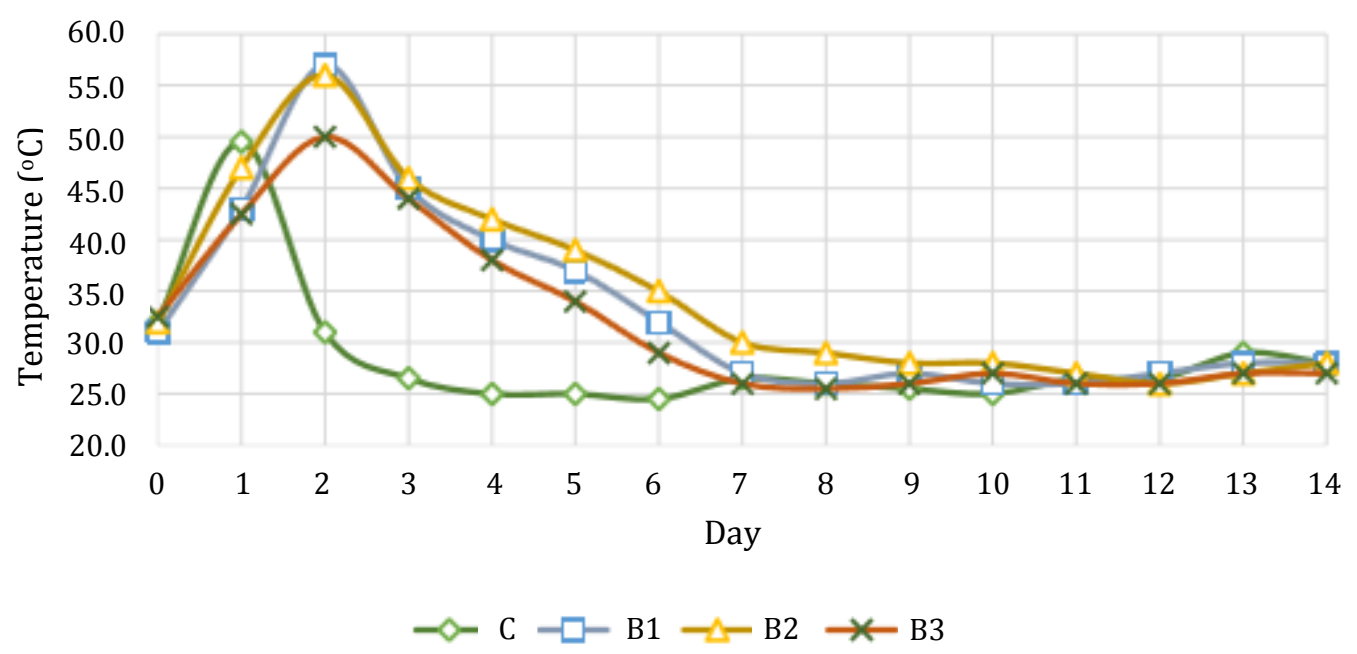

Figure 2. The graph of changes in compost temperature 
After reaching the peak, the temperature of the composting process began to decrease on the 4 th and 6th days. This was called as the mesophilic phase with temperatures ranging from $27^{\circ} \mathrm{C}$ to $47^{\circ} \mathrm{C}$. In this phase, mesophilic microorganisms will remodel the remaining cellulose and hemicellulose from the previous process. On the seventh to the fourtenth days, there was a relatively uniform (stable) increase and a decrease in temperature at each reactorures ranging from $26^{\circ} \mathrm{C}-29^{\circ} \mathrm{C}$. In this phase, organic matter was decomposed and $\mathrm{C}$ level decreased so that the energy needed by the bacteria to move also decreased, causing many bacteria to die. In the composting process, the material was stirred to mix it with bacteria to produce good compost and to regulate the entry of oxygen into the compost pile from the aeration process.

\subsubsection{Degree of acidity}

The acidity was measured every day during 14-day composting using a digital pH meter. The acidity $(\mathrm{pH})$ is a critical factor in the growth of microorganisms in compost. The function of this $\mathrm{pH}$ measurement is to determine the condition of the reactor in an acidic, basic or neutral state.

At the beginning of the composting process, the $0 \mathrm{pH}$ could be obtained at reactors control (5.2), reactor B1 (5.2), reactor B2 (5.0) and reactor B3 (5.0) experiencing a decrease in pH along with the increase in temperature on the 1st and 2nd day. At the beginning of the process, the $\mathrm{pH}$ decreased due to the activity of microorganisms form organic acids. After decreasing, the $\mathrm{pH}$ value increased until it reached the highest $\mathrm{pH}$ of 8.2 in the $\mathrm{B} 1$ reactor on the 8th day. This was due to the formation of $\mathrm{NH}_{3}$ during the decomposition process and the presence of dolomite lime in which dolomite lime also increased the soil $\mathrm{pH}$, because dolomite lime was dissociated into $\mathrm{Ca}^{2+}, \mathrm{Mg}^{2+}$, and $\mathrm{CO}_{3}{ }^{2}$-ions in the soil and due to an increase in the $\mathrm{pH}$ value, odor produced in the composting process also reduced and removed the smell of the soil (Danner, 2010). Dolomite increased the soil $\mathrm{pH}$ and supply of $\mathrm{Mg}$ and $\mathrm{Ca}$ shifted the position of $\mathrm{H}^{+}$on the colloidal surface so the soil acidity could be neutralized

From day 10 to 14, the $\mathrm{pH}$ was shown to be stable. This shows that the compost in mature conditions was control ractor (7.5), reactor B1 (7.8), reactor B2 (8.0) and reactor B3 (8.0). This decreased because of the enzymatic oxidation of inorganic compounds resulted from the decomposition process and was suspected to be caused by the microorganisms in the composting process which were in the stationary phase, where the degradation activity will be stable so that the heat produced tends to be stable. According to Minister of Agriculture Regulation No. 70 of 2011, the good pH for solid organic fertilizers was the maximum of 9 .

\subsubsection{Moisture}

According to Som et al. (2009) one of the key factors indicating that composting runs fast is the water content. Water content has an important role in composting because the decomposition of organic material depends on it.

In this composting process, the main ingredients were food waste chopped using a chopper and produced 78.94 of moisture. In the composting process, too high water content causes anaerobic conditions, because pores are more dominantly filled by water than air so that the availability of oxygen is limited. Because food waste has high water content, it is necessary to add bulking agents which in this case was the compost. It was to provide a supporting structure for the pile of materials, providing air pores between particles and facilitating the movement of air through the mixture of materials to obtain an initial water content of 50-60\% mixture. Then, the main ingredient (food waste) was calculated with a bulking agent (compost) because the water content of 50-60\% was the optimum condition for developing microbes. A good balance between the pore space and the amount of water allowed microbes to develop well in degrading organic matter. Changes in water content in the composting process can be seen in Figure 3. 


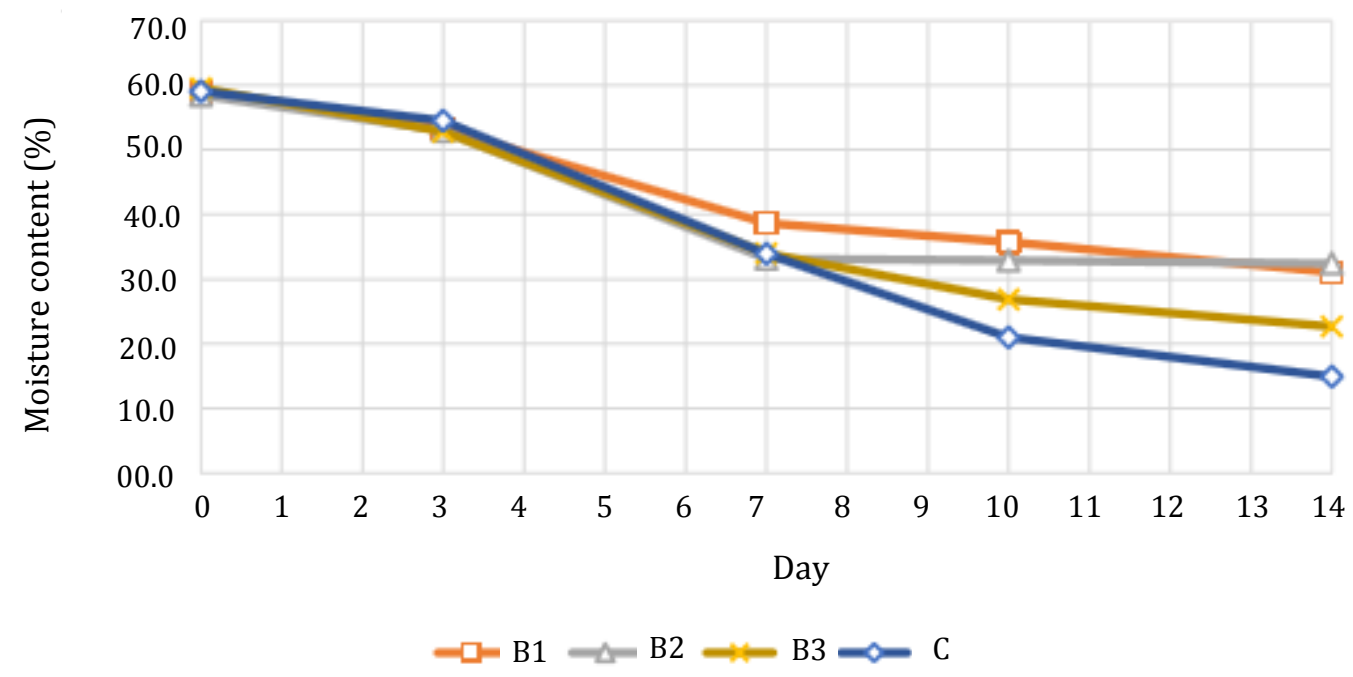

Figure 3. Graph of the relationship between moisture content and composting time

Based on Figure 3, each reactor has decreased during the composting time. The highest water content was in the reactor B1 while the lowest was in the control reactor. The difference in water content with the same composition can be caused by the inadequate stirring so that there were still some ingredients not exposed to aeration. In this composting process, the aerated discharge was used at 3 liters/minute. Based on some previous related research, the use of 3 liters/minutes aeration discharge was able to produce a small amount of leachate indicating the low water content in composting. The presence of aeration affects the production of leachate. The water content in waste decreases through two phases, namely the evaporating water molecules (from the liquid to the gas) from the surface of the waste to the surrounding air, both evaporated water will be transported by air flow from aeration and transferred to the outside air.

Based on research, the water content in all reactors fulfill the criteria specified by SNI 197030-2004 which is the minimum water content of less than 50\%. While the results of the study show that on the 7-14th day the water content in all reactors had reached $\pm 30 \%$. The decrease in water content that occurs during the aerobic composting process was caused by the consumption of microorganisms in water and the presence of reversal or stirring activity (Ayuningtyas, 2009).

\subsubsection{C/N Ratio}

The $\mathrm{C} / \mathrm{N}$ ratio indicates the decomposition process in composting and compost maturity has occurred. It is obtained from the comparison between carbon and nitrogen. Elements of carbon and organic matter are for example carbohydrates while the ones of nitrogen are e.g. protein, nitric acid, ammonia, etc. Microbes break down compound $\mathrm{C}$ as an energy source and use $\mathrm{N}$ for protein synthesis. Carbon element (C) produces energy while nitrogen (N) builds cell and bacterial structures. If the $\mathrm{C}$ ratio is too high, microbes will lack $\mathrm{N}$ for protein synthesis so the decomposition runs slowly. The relationship between the addition of bio-activator and the time of composting to the $\mathrm{C} / \mathrm{N}$ ratio can be seen in Figure 4 .

Based on research data, the four reactors had different $\mathrm{C} / \mathrm{N}$ ratios and experience both increases and decreases during the composting process until the end of the study. Fluctuation that occurred was influenced by the type of organic material used and ideal conditions in the pile where microorganisms could grow and develop rapidly. On day 0 the results of the $\mathrm{C} / \mathrm{N}$ ratio were around 26-29 and on the last day of composting (the 14th day), there was a decline of around 1319. Overall, the value of the $\mathrm{C} / \mathrm{N}$ ratio of all reactors tended to decrease and in accordance with the 
regulations of SNI 19-7030-2004, this occurred after nitrogen and protein were broken down into ammonia. In this case, a nitrification process occurred that converted ammonia to nitrate. The highest $\mathrm{C} / \mathrm{N}$ ratio results in the B3 reactor, 19.48. According to Azizah et al. (2017), in the decomposition of organic matter, some $\mathrm{C}$ will be assimilated in microorganisms and some will be lost in the form of $\mathrm{CO}_{2}$ by the process of respiration. The $\mathrm{C} / \mathrm{N}$ ratio of microorganisms ranged from 10. Therefore, if the material had a high $\mathrm{C} / \mathrm{N}$ ratio, it had to be received additional $\mathrm{N}$, and if the $\mathrm{C} / \mathrm{N}$ ratio of organic matter was low then too much $\mathrm{N}$ will be lost. Different results on $\mathrm{B} 3$ variations were the increase in the $\mathrm{C} / \mathrm{N}$ ratio on days 7 to 14 . The rise of $\mathrm{C} / \mathrm{N}$ ratio value was also influenced by the compost pile in an alkaline state, leading $\mathrm{NH}^{+}$to be insufficient for $\mathrm{NH}_{3}$ to be converted to $\mathrm{NH}_{4}^{+}$so that $\mathrm{NH}_{3}$ was volatilized to $\mathrm{N}_{2}$ into the air, and resulted in a slight increase in N levels. In addition, it was also influenced by the level of $\mathrm{C}$ in the composting material used. Too much $\mathrm{C}$ content in the food material produces a high $\mathrm{C}$ value.

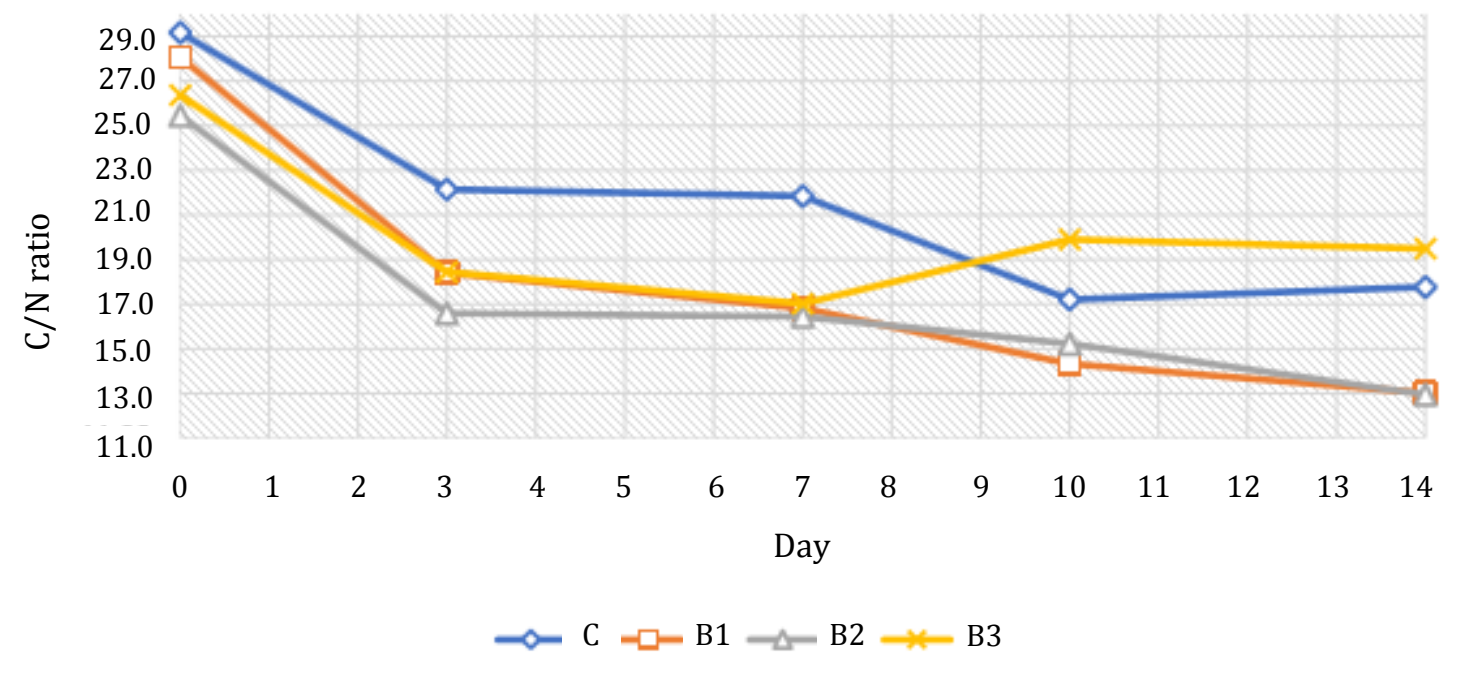

Figure 4. Graph of the $\mathrm{C} / \mathrm{N}$ ratio when composting

The length of time composting organic material with the aerobic method, according to Tchobanoglous \& Kreith (2002), ranges from 20 to 30 days. Based on the description, it was found that the addition of two different compositions of additive microorganism accelerates composting time to 7 and 14 days. The addition of activators was proven to be able to decompose organic matter effectively so that the ripening process could be faster and in according to Ariyanti (2018), bulking agents (mature compost) are used in the composting process as a medium for air movement by increasing porosity, absorption, and degradation rates of the composting material. The composting time is influenced by the initial $\mathrm{C} / \mathrm{N}$ ratio because the higher the $\mathrm{C} / \mathrm{N}$ ratio is, the longer the composting will last. Broadly speaking, the results of the $\mathrm{C} / \mathrm{N}$ ratio on all compost variations at the end of the experiment successfully met the SNI 19-7030-2004 mature compost with the $\mathrm{C} / \mathrm{N}$ ratio of $10-20$.

\section{Conclusions}

The best composition between food waste and additive microorganisms for composting is 7:3. To get a much better result, the addition of 1 gram of dolomite lime is necessary. The composting time in reactors B2 and B3 was more effective which was just seven days compared 
to reactors $\mathrm{K}$ and $\mathrm{B} 1$ which reached 14 days. The reactor $\mathrm{B} 2$ had a $\mathrm{C} / \mathrm{N}$ ratio of 16.71 and the reactor $\mathrm{B} 3$ had a $\mathrm{C} / \mathrm{N}$ ratio of 18.37 , then the composting time in the reactor $\mathrm{B} 2$ was more effective ( 7 days) and had a better compost maturity.

\section{Acknowledgment}

Thank you, the writer conveyed to the Department of Environmental Engineering, Faculty of Engineering, Diponegoro University, which has facilitated laboratory and funded the study (RKAT of Faculty of Engineering Universitas Diponegoro in 2018).

\section{References}

Ariyanti, V. T. D. (2018). Efektifitas Penggunaan Bulking Agents Berupa Tongkol Jagung (Corncobs), Jerami Padi (Chopped Mature Hay) dan Serut Kayu (Wood Shaving) Dalam Proses Pengomposan Limbah Sisa Makanan. Uinversitas Diponegoro.

Ayuningtyas, D. N. (2009). Pengaruh Sistem Aerasi dan Ketersediaan Oksigen Terhadap Laju Proses Pemgomposan dan Kualitas Kompos Berbahan Baku Limbah Pencucian Biji Kakao Terfermentasi, Serasah Daun dan Kotoran Sapi. Institut Pertanian Bogor.

Azizah, A., Zaman, B., \& Purwono, P. (2017). Pengaruh Penambahan Campuran Pupuk Organik Kotoran Sapi dan Kambing Terhadap Kualitas Kompos dari Sampah Daun Kering di TPST UNDIP. Theses. Universitas Diponegoro, Semarang.

Barrena, R., Font, X., Gabarrell, X., \& Sánchez, A. (2014). Home composting versus industrial composting: Influence of the composting system on compost quality with a focus on compost stability. Waste Management, 34(7), 1109-1116.

Bernal, M. P., Alburquerque, J. A., \& Moral, R. (2009). Bioresource Technology Composting of animal manures and chemical criteria for compost maturity assessment. A review. Bioresource technology, 100(22), 5444-5453.

Danner, S. (2010). Peningkatan pH tanah masam di lahan rawa pasang surut pada berbagai dosis kapur untuk budidaya kedelai. Jurnal Agroqua, 8(2), 1-5.

Fan, Y. Van, Tin, C., Roji, M., \& Woh, C. (2017). Evaluation of Effective Microorganisms on home scale organic waste composting. Journal of Environmental Management, 216, 41-48.

Justice, J., Tucker, P., Speirs, D., Fletcher, S. I., Edgerton, E., \& Mckechnie, J. (2010). Local Environment: The International Factors Affecting Take-up of and Drop- Factors Affecting Take-up of and Drop-out from Home Composting Schemes, (March 2015), 37-41. https://doi.org/10.1080/13549830306660

Keener, H. M., Dick, W. A., \& Hoitonk, H. A. J. (2000). Composting and Beneficial Utilization of Composted By-Product Materials. Ohio, USA.: Ohio Agricultural Research and Development Center, Wooster, Ohio, USA. https://doi.org/10.2136/sssabookser6.c10

Pereira, B. F. F., He, Z., Stoff, P. J., Montes, C. R., Melfi, A. J., \& Baligar, V. C. (2012). Nutrients and Nonessential Elements in Soil after 11 Years of Wastewater Irrigation, Journal of Environmental Quality, 41(3), 920-927. https://doi.org/10.2134/jeq2011.0047

Simanungkalit, R. D. M., Didi, A. S., Rasti, S., Diah, S., \& Wiwik, H. (2006). Pupuk Organik dan Pupuk Hayati. Jawa Barat: Balai Besar Penelitian dan Pengembangan Sumberdaya Lahan Pertanian. 
Som, M., Lemée, L., \& Amblès, A. (2009). Bioresource Technology Stability and maturity of green waste and biowaste compost assessed on the basis of a molecular study using spectroscopy, thermal analysis, thermodesorption and thermochemolysis, Bioresource technology, 100(19), 4404-4416. https://doi.org/10.1016/j.biortech.2009.04.019

Tchobanoglous, G., \& Kreith, F. (2002). Handbook of Solid Waste Management Second Edition (Second). New York: McGraw-Hill.

Zhang, D., He, P., Jin, T., \& Shao, L. (2008). Bioresource Technology Bio-drying of municipal solid waste with high water content by aeration procedures regulation and inoculation, Bioresource Technology, 99

https://doi.org/10.1016/j.biortech.2008.04.046

(18),

8796-8802. 